\title{
Ebola Hemorrhagic Fever
}

National Cancer Institute

\section{Source}

National Cancer Institute. Ebola Hemorrhagic Fever. NCI Thesaurus. Code C36171.

A viral hemorrhagic fever that is caused by the Ebola virus, which is transmitted by contact with infected animals or humans; it is characterized by high fever, unexplained bleeding, and a high mortality rate. 